\title{
Implementation, its termination phase of Japan-Indonesia collaborative and future studies of breast cancer
}

\author{
Santoso Cornain*, Yoshiyuki Ohno*
}

\begin{abstract}
Abstrak
Kanker payudara tetap merupakan masalah, baik untuk negara-negara dengan angka kejadian yang tinggi maupun untuk negaranegara dengan angka kejadian yang rendah, oleh karena pengetahuan terbatas tentang patogenesis dan penatalaksanaan klinikopatologik. Penelitian kerjasama Jepang-Indonesia tentang Etiologi dan Klinikopatologi dari Kanker Payudara telah dilaksanakan sejak 1988 sampai 1996. Proyek tersebut didukung oleh dana Proyek Penelitian Internasional tentang Kanker dari Kernentrian Pendidikan, Olahraga dan Kebudayaan Jepang, dengan persetujuan dari Dekan Fakultas Kedokteran Universitas Indonesia. Bantuan sebagian diberikan oleh Yayasan Kanker Indonesia. Desain penelitian dalam dua fase diterapkan, yaitu penelitian dari tiga segi, termasuk aspek epidemiologik, klinik dan histopatologik diteliti dalam tahap pertama (3 tahun), yang diperpanjang dalam tahap kedua dengan penekanan kepada analisa gizi yang lebih lanjut. Manajemen penelitian diterapkan berdasarkan lima fase manajemen proyek (2 fase perencanaan; penetapan dan perencana dan 3 fase implementasi; pengorganisasian, pengawasan dan penutupan atau pengakhiran), dengan penyesuaian kepada proyek penelitian ilmiah. Sesuai dengan penelitian dalam dua fase, maka fase-fase manajemen proyek dilaksanakan dalam dua siklus. Dalam fase implementasi dilaksanakan pengorganisasian tim-tim yang terkait, termasuk Nagoya City University, Nagoya University School of Medicine - Nagoya, Cancer Institute - Tokyo dan Fakultas Kedokteran Universitas Indonesia, Jakarta, serta Pusat Penelitian dan Pengembangan Gizi, Bogor. Hasil-hasil yang dihargai telah diperoleh selama fase penelitian tahap pertama dan oleh karena itu, dana bantuan penelitian telah diperpanjang agar dapat melakukan analisa gizi lebih lanjut. Tim multidisiplin telah dapat mewujudkan cara kerja tim yang baku dan berusaha keras untuk mencapai tingkat kinerja yang tinggi. Hasil-hasil yang bermakna telah dibahas dalam Simposium sehari yang pertama dan telah dipublikasikan dalam monograf pertama pada akhir penelitian tahap pertama. Seyogyanya, hasil-hasil penelitian tahap kedua dengan penekanan kepada analisa gizi lebih lanjut dibahas dalam Simposium sehari kedua dan dipublikasikan dalam monograf kedua ini. Fase penutupan atau pengakhiran dari proyek telah diatur dalam kombinasi tipe inklusi dan tipe integrasi. Yang pertama memungkinkan pelembagaan dari kerjasama penelitian kanker payudara dalam tatanan multidisiplin dan yang kedua menggalakkan proyek penelitian berkesinambungan yang diorganisasikan dalam berbagai kelompok dan bagian. Penelitian-penelitian yang akan datang telah direncanakan baik untuk analisa gizi lebih lanjut berdasarkan penelitian epidemiologi lapangan dan penelitian klinikopatologik lebih lanjut, termasuk klinikopatologi molekuler.
\end{abstract}

\begin{abstract}
Breast cancer remains a problem both for countries with high incidence and for countries with low incidence, due to limited knowledge in its pathogenesis and clinicopathological management. The Japan-Indonesia Joint Study on the Etiology and Clinicopathology of Breast Cancer has been conducted since 1988 to 1996. The project has been supported by the grants for International Research Projects on Cancer of the Ministry of Education and Culture, Japan with the approval by the Dean. Partial support has been provided by the Indonesian Cancer Foundation. The study has been designed in two phases: three fold studies including epidemiological, clinical and histopathological aspects were investigated duiring the first batch (3 years), which was extended in the second batch ( 3 years) with the emphasis on further nutritional analysis. The research management has been applied based on 5-phase project management $(2$ phases of planning: defining and planning and 3 phases of implementation: organizing, controlling and closing or termination), with adjustment to scientific research project. Since the project was set up in two phases, the research management phases have been applied in two cycles. The implementation has dealt with organizing the relevant teams, including Nagoya City University, Nagoya University, Nagoya and Cancer Institute, Tokyo and University of Indonesia and Dr. Cipto Mangunkusumo Hospital, Jakarta. Appreciable results have been achieved during the first batch of study and therefore the grant has been extended to allow further nutritional analysis. The multidisciplinary team has been able to pursue basic teamwork and made great attempts to achieve high performing stage. Significant results have been discussed in the first One-day Symposium and a Monograph has been published at the end of the first batch of study. Accordingly, results of the second batch of study with the emphasis of further nutritional analysis will be discussed in the second One-day Symposium and published in the second Monograph. The closing or termination phase of the project will be arranged in the combination of the inclusion and the integration types. The former would allow the institutionalization of the collaborative research on breast cancer in multidisciplinary setting and the latter would encourage the on-going research project as organized in different groups and departments. The future studies have been planned for setting up both further nutritional analysis based on field epidemiological study and further clinicopathological study including molecular pathological study.
\end{abstract}

Keywords: Japan-Indonesia, collaborative study, implementation, termination, breast cancer.

\footnotetext{
* Department of Anatomic Pathology, Faculty of Medicine, University of Indonesia, Jakarta 10430, Indonesia

\# Department of Preventive Medicine, School of Medicine, Nagoya University, Nagoya 466, Japan
} 


\section{INTRODUCTION}

Common interest between Indonesia and Japan on the study of breast cancer has been based on similar situation in several respects. Firstly, in respect to geographical area and ethnical group i.e. Asia and Africa, I secondly, due to the fact that the breast cancer ranked the second and remained so within 5 year period (from 1988 to 1992) with age standardized cancer ratio around $17-18 \%$ in pathology based cancer registry with similar position in limited population-based cancer registry, ${ }^{2-4}$ while in Japan increasing incidence was seen in later studies $5-9$ i.e. from 12.1-16.6 to 21 per 100.000 females, particularly in the age range 40-79 years, albeit lower than the incidence in America. It is of interest, that increasing trend was also seen in America i.e. from 71.7 to 91 per 100.000 females. The problem on breast cancer remains important due to such difference in the incidence, limited knowledge in its pathogenesis and clinicopathological management. Moreover, the investigators concerned about increasing mortality rate as observed in Japan, i.e. age-adjusted mortality rate has been increasing since the $1960 \mathrm{~s}$ (4.1 per 100.000 population in 1950 and 6.6 in 1991, adjusted by the World Population) ${ }^{9}$

Based on such common interests to study both similarity and dissimilarity between the Japanese and the Indonesian breast cancer patients, a Japan-Indonesia Joint Study on the Etiology and Clinicopathology of Breast Cancer has been set up in two phases. During the first batch three fold study, i.e. epidemiological, clinical and histopathological aspects, has been carried out. Relevant to the interesting results, in particular on the significant findings that fatty food increased the risk of breast cancer, the study has been extended with the second batch, in order to allow further nutritional analysis.

The research management has been worked out based on standard 5-phase project management, 10,11 2 phases of planning (definition and planning) and 3 phases of implementation (organizing, controlling and closing or termination), with adjustment to research project.12,13 In order to fit to the two-phases study, the project management phases have been applied in two-cycles. The present paper will discuss the implementation phase of project management, including the management / control and its termination and the future studies.

\section{THE IMPLEMENTATION OF JOINT STUDY}

Following careful situation analysis, the definition and planning of the research project, the multidisciplinary team has been built. The Japanese team has been initiated with the epidemiologists from the Nagoya City University and later from the Nagoya University, Nagoya and the surgeon and pathologist from the Cancer Institute, Tokyo, while the Indonesian team consisted of epidemiologists, surgeons, and pathologists from Faculty of Medicine/Dr. Cipto Mangunkusumo Hospital, Jakarta. The joint study has been initiated with 2-month Pilot Study from December 1988 and January 1989, while the Definitive Study has been performed from May 1989 to November 1991. Standard case-control study was set up in three-fold study, i.e. epidemiological, clinical and histopathological aspects. Cases were women with primary breast cancer, histopathologically confirmed and aged ranging from 25 to 69 years. Two controls were selected from women visiting the same clinic without lump, matched by age, circa 3 years, and socioeconomic status. During the first batch, 300 cases and 600 controls were collected. Both similarity and dissimilarity between the Japanese and the Indonesian breast cancer patients were encountered in clinical, histopathological and epidemiological aspects. Both teams were interested in the results indicating that fatty food consumption significantly increased the risk of breast cancer. The study was then extended for another three years, from April 1992 to March 1995, to allow further nutritional analysis. During the second batch, 226 cases and 452 controls were collected.

In order to extend nutritional study with special attention to micronutrient analysis, two nutritionists belonging to the Faculty of Medicine, University of Indonesia and the Nutritional Research Center, Ministry of Health with their assistants were added to the team. In collecting the nutritional data, they were to work independently but in good coordination with the responsible persons for collecting the epidemiological data. The data were treated for further processing and analysis according the established flow chart. Accordingly, the flow chart was used in managing/controlling of the project activity and performance. Besides regular team meetings, consultation meetings between the Indonesian and the Japanese team were carried out in tight schedules, i.e. 3-4 times a year. Such efforts have been suggested in team building and to achieve high performing team. 14 
Progress reports were produced in every consultation meeting. As to complete the research requirements, the results were reported in institutional symposium or presented in both national and international conferences, and documented in manuscripts published in both national and international journals. 15,16 The results were also documented in two Monographs, the first monograph for the first batch of study and the present monograph for the second batch of study.

\section{THE TERMINATION OF THE PROJECT AND ITS FUTURE STUDIES}

In accordance with the interesting findings revealed, the project termination has been arranged by inclusion and by integration. ${ }^{10}$ The success has been accepted both at the departmental level and at the higher institutional level.

The teams consider that the research activity would be developed further. Therefore, further nutritional analysis are being arranged in a field nutritional study in a multicenter setting, in comparing two different ethnic groups with different food habits, namely West Sumatera with population used to consume more fatty food and less fresh vegetables compared to West Java with population used to consume less fatty food and more fresh vegetables. The design and planning has been discussed thoroughly in a special workshop participated by the team members in the coordinating center and the regional centers. An improvement has been made by introducing the principle of strategic planning. ${ }^{17,18}$ The implementation of this multicenter is in progress.

The future studies are also aimed to analyze the problems of breast cancer in its molecular pathological aspects as comprehensively studied by various investigators in relationship with the biological behaviors of breast cancer and its prognosis. ${ }^{19-21}$

\section{Acknowledgments}

The authors are grateful to Prof. Haruo Sugano, Cancer Institute Hospital, Tokyo, Profs. Kunio Aoki and Suketami Tominaga, Aichi Cancer Center, Nagoya and the Dean, Faculty of Medicine, University of Indonesia, Jakarta for the arrangements and the authorization of the collaborative project. The authors are also indebted to the Director of Dr. Cipto Mangunkusumo National Central General Hospital and the Heads of the Departments of Surgery, Community Medicine, Anatomic Pathology, Nutrition, Faculty of Medicine, University of Indonesia and the Director of Research and Development Center for $\mathrm{Nu}$ - trition, Ministry of Health, Bogor for allowing excellent multidisciplinary team building and implementation of the project.

This work was supported by the Ministry of Education, Science, Sports and Culture of Japanese Government, Grants No. 01042007, 04042013, 06042006 and was partly supported by the Indonesian Cancer Foundation. This collaborative study was a part of Special Cancer Research Project in Monbusho International Scientific Research Program, with the approval of the Dean, Faculty of Medicine, University of Indonesia, No. 4383/PT02.H4.FK/E/88. We would like to thank to Devieta Sari and Dewi for word processing.

\section{REFERENCES}

1. Parkin DM. The nature and sources of cancer data from developing countries. In: Khogali M, Omar YT, Gjorgov A, Ismail AS, editors. Cancer prevention in developing countries. Proceedings of the $2^{\text {nd }}$ UICC Conference on Cancer Prevention, Kuwait, 1986. Oxford: Pergamon Press, 1986: 9-22.

2. Prihartono J, Mangunkusumo R, Partoatmodjo O. Establishing pathology based cancer registry: Indonesian experience. In: Sasaki R, Aoki K, editors. Epidemiology and Prevention of Cancer. Proceedings of Monbusho (Ministry of Education, Science \& Culture) International Symposium on Comparative Study of Etiology \& Prevention of Cancer, Nagoya, 1989. Nagoya: The University of Nagoya Press, 1990: 211-6.

3. Pathology based Cancer Registry Data of 1988-1992. In: Cancer Registry in Indonesia. National Cancer Registry Center, Jakarta Coordinating Board, 1994.

4. Sarjadi. Cancer Incidence 1985-1989 in Semarang, Indonesia. Indonesian Cancer Society, 1990.

5. WHO, IARC. Cancer Incidences in Five Continents. IARC Sci Publ No.15, Vol.III, Lyon, France.

6. Parkin DM, Laara E, Muir CS. Estimates of the worldwide frequency of sixteen major cancers in 1980 . Int $\mathbf{J}$ Cancer 1988; 41: 1184-97.

7. Donn AS, Muir CS. Breast cancer. Epidemiology and risk factors. In: Khogali M, Omar YT, Gjorgov A, Ismail AS, editors. Cancer prevention in developing countries. Proceedings of the $2^{\text {nd }}$ UICC Conference on Cancer Prevention, Kuwait, 1986. Oxford: Pergamon Press, 1986: 155-66.

8. Hanai A, Fujimoto I. Population-based cancer registry in Japan. In: Sasaki R, Aoki K, editors. Epidemiology and Prevention of Cancer. Proceedings of Monbusho (Ministry of Education, Science \& Culture) International Symposium on Comparative Study of Etiology \& Prevention of Cancer, Nagoya, 1989. Nagoya: The University of Nagoya Press, 1990:199-200.

9. Wakai K, Suzuki S, Ohno Y, Kawamura T, Tamakoshi A, Aoki R. Epidemiology of breast cancer in Japan. Int $J$ Epidemiol 1995; 24: 285-90. 
10. Weiss JW, Wysocki RK. 5-phase project management: A practical planning and implementation guide. Massachusetts: Addison-Wesley Publishing Co., 1992.

11. Michael N, Burton C, Basic project management. Singapore: Singapore Institute of Management and Heinemann Asia, 1992.

12. Hawkins C, Sorgi M. Research: How to Plan, Speak and Write about it. Singapore: Narosa Publishing House, Toppan Company (S) Pte. Lt15d,, 1992.

13. Boyd NF. Epidemiology of Cancer. In: Tannock IF, Hill RP, editors. The Basic Science of Oncology. $2^{\text {nd }}$ ed. New York: McGraw-Hill Inc., 1992: 7-22.

14. Dyer WG. Team building: Current Issues and New Alternatives. $3^{\text {rd }}$ ed. New York: Addison-Wesley Publishing Co., 1995.

15. Cornain S, Ohno Y, Prihartono Y, Sakamoto G, Tjahjadi G, Tjindarbumi D, Wakai K, Ramli M, Budiningsih S, Suzuki S, Darwis I, Watanabe S, Sri Roostini E, Dillon DS, Herman S. Similar and dissimilar findings in Japan-Indonesia case-control study on breast cancer: Two phases study. J Epidemiol 1996; 6: 175-80.

16. Cornain S, Ohno Y, Dillon DS, Prihartono J, Sakamoto G,
Tjahjadi G, Tjindarbumi D, Wakai K, Ramli M, Sutrisno E, Budiningsih S, Suzuki S, Darwis I, Sri Roostini E, Herman S. Nutritional risk factor analysis in Japan-Indonesia joint study on breast cancer. Jpn J Cancer Clin 1997; 43: 413-9.

17. Gaynor AK, Evanson JL. Project planning: a guide for practitioners. Boston: Allyn and Bacon, 1992.

18. Buttrick R. The project work out. London: Financial times, Pitman Publishing,1997.

19. Iwaya K, Tsuda H, Hiraide H, Tamaki K, Tamakuma S, Fukutomi T, Mukai K, Hirohashi S. Nuclear p53 immunoreaction associated with poor prognosis of breast cancer. Jpn J Cancer Res 1991; 82: 835-40.

20. Takikawa Y, Nogichi M, Kitagawa H, Thomas M. Immunohistochemical detection of $\mathrm{p} 53$ and c-erb B-2 proteins: prognostic significance in operable breast cancer. Breast Cancer 1994;1:17-23.

21. Narita T, Funahashi H, Imai T, Takagi H. Correlation between the concentration of c-erb B-2 protein, EGF-receptor and TGFa in breast cancer tissue, and clinicopathological parameters. Breast Cancer 1994;1:57-9. 